\title{
Pharmacokinetics of tinidazole and metronidazole in women after single large oral doses
}

\author{
B. A. WOOD AND A. M. MONRO \\ Department of Drug Metabolism, Central Research, Pfizer Ltd., Sandwich, Kent
}

Metronidazole (I) and tinidazole (II) are two structurally related drugs which possess similar inhibitory potencies in vitro $v$. Trichomonas vaginalis (Howes, Lynch, and Kivlin, 1970).<smiles>Cc1ncc([N+](=O)[O-])n1CCO</smiles><smiles>CCOS(=O)(=O)CCn1c([N+](=O)[O-])cnc1C</smiles>

Despite this similarity, the normally recommended total dosage for clinical use of metronidazole* is about $4 \mathrm{~g} ., \ddagger$ while that recommended for tinidazole $\dagger$ is about $2 \cdot 1 \mathrm{~g} . \ddagger$ In a study of the serum levels achieved by the two drugs in female volunteers, it was shown that the different dosage apparently required for equal clinical results could be explained by a comparison of the kinetics of the two drugs in man, the serum half-life of tinidazole being double that of metronidazole (Welling and Monro, 1972).

Both drugs have been found to be remarkably free from side-effects in clinical use, and this has justified the evaluation of regimens for both drugs in which either a single dose or two successive daily doses have been given (Csonka, 1971; Woodcock, 1972; Rösemann and Vaughan, 1973). In the present study we have compared the pharmacokinetics of the two drugs when administered in $2 \mathrm{~g}$. single doses to twelve healthy females in a cross-over study.

\section{Methods}

Tinidazole and metronidazole were compared in a twoway cross-over study using twelve normal healthy female

Received for publication April 30, 1974

Address for reprints: Dr. B. A. Wood, Department of Drug Metabolism, Central Research, Pfizer Ltd., Sandwich, Kent

$\star$ Flagyl $@$, May and Baker

†Fasigyn ®, Pfizer

F Flagyl: $200 \mathrm{mg}$. three times a day for 7 days or $2 \mathrm{~g}$. (in divided dosage) on each of two successive days

Fasigyn: $150 \mathrm{mg}$. twice daily for 7 days or $150 \mathrm{mg}$. three times a day for 5 days volunteers, six in each group. After an overnight fast, followed by a light breakfast, a single dose of either tinidazole or metronidazole was taken with $100 \mathrm{ml}$. water. No food or drink was consumed for $2 \mathrm{hrs}$ thereafter. 2 weeks later the same procedure was followed, each subject receiving the alternative drug. The dose for both drugs was $2 \mathrm{~g}$. ( $4 \times 500 \mathrm{mg}$. 'Fasigyn' tablets; $5 \times 400 \mathrm{mg}$. 'Flagyl' tablets).

Blood was taken from a forearm vein at intervals up to $72 \mathrm{hrs}$ after taking the dose, and serum was prepared for assay by microbiological and chemical methods.

\section{Bioassay}

Serum samples were diluted with a meat extract/liver medium (D. Buggey, to be published) and inoculated with a clinical isolate of $T$. vaginalis. After incubation at $37^{\circ} \mathrm{C}$. for $48 \mathrm{hrs}$ the cultures were examined, and the highest dilution giving complete inhibition of motility taken as the end-point. The limit of detection is $4 \mu \mathrm{g} . / \mathrm{ml}$. for tinidazole, and $2 \mu \mathrm{g} . / \mathrm{ml}$. for metronidazole.

\section{Chemical assay}

The thin layer chromatographic (t l c) method described by Welling and Monro (1972) was used, except that concentrations were determined by reference to a calibration curve prepared for each $t \mathrm{l}$ plate by extracting serum containing known amounts of the drug. The concentration limit of the assay is $0.5 \mu \mathrm{g} . / \mathrm{ml}$. for both drugs.

\section{Results and discussion}

The mean serum concentrations of the two drugs obtained by the microbiological and chemical assays are listed in Table I. Peak serum levels for both drugs occurred between 1 and $2 \mathrm{hrs}$ after taking the dose. The chemical assay showed that tinidazole achieved a higher mean peak concentration (51 $\mu \mathrm{g} . / \mathrm{ml}$.) than did metronidazole $(40 \mu \mathrm{g} . / \mathrm{ml}$.). whereas the bioassay showed a mean peak concentration for metronidazole $(81 \mu \mathrm{g} . / \mathrm{ml}$.) higher than that for tinidazole $(67 \mu \mathrm{g} . / \mathrm{ml}$.).

The discrepancy between the apparent serum concentrations of tinidazole and metronidazole measured by the two assays can be explained by differences in the metabolism of the drugs. For tinidazole, apart from the values at $4 \mathrm{hrs}$, the two sets of assay results are not significantly different 
TABLE I Mean serum concentrations ( $\mu \mathrm{g} . / \mathrm{ml} . \pm$ s.e.m.) of metronidazole and tinidazole after administratıon of a $2 \mathrm{~g}$. dose to healthy female volunteers

\begin{tabular}{|c|c|c|c|c|}
\hline \multirow{2}{*}{$\begin{array}{l}\text { Time } \\
\text { (hrs) }\end{array}$} & \multicolumn{2}{|l|}{ Chemical assay } & \multicolumn{2}{|l|}{ Bioassay* } \\
\hline & Metronidazole & Tinidazole & Metronidazole & Tinidazole \\
\hline $\begin{array}{l}0.5 \\
1 \\
2 \\
4 \\
6 \\
24 \\
48 \\
72\end{array}$ & $\begin{array}{l}35 \pm 6 \\
40 \pm 5 \\
39 \pm 4 \\
38 \pm 2 \\
32 \pm 2 \\
5 \cdot 7 \pm 0.8 \\
0.9 \\
N D\end{array}$ & $\begin{array}{l}23 \pm 5 \\
41 \pm 5 \\
51 \pm 4 \\
46 \pm 4 \\
42 \pm 3 \\
19 \pm 2 \\
4 \cdot 2 \pm 0.6 \\
1 \cdot 3 \pm 0.1\end{array}$ & $\begin{array}{l}31 \pm 7 \\
69 \pm 9 \\
81 \pm 17 \\
40 \pm 7 \\
20 \pm 4 \\
3 \pm 1 \\
N D \\
N D\end{array}$ & $\begin{array}{l}21 \pm 11 \\
65 \pm 19 \\
67 \pm 15 \\
65 \pm 8 \\
43 \pm 10 \\
13 \pm 3 \\
3 \\
\text { ND }\end{array}$ \\
\hline
\end{tabular}

$\mathrm{ND}=$ none detected

*The bioassay results are expressed as $\mu$ g. equivalents of tinidazole or metronidazole per ml. One subject completed only the metronidazole half of the study, due to discomfort associated with venepuncture.

$(P>0 \cdot 1)$, which suggests that the biologically active material in serum is unchanged tinidazole. This is consistent with our laboratory finding that, in subjects who had taken tinidazole, the assay of serum by a polarographic method (which measures both drug and metabolites containing the nitroimidazole moiety) gave the same results as the drug-specific $\mathrm{t} l \mathrm{c}$ method used in this study. The data for metronidazole show that the bioassay results at 1 and $2 \mathrm{hrs}$ are significantly higher $(P<0.05)$ than the chemical assay results, suggesting the presence of active metabolites in the serum for the first few hours after taking the drug. This is in accord with the report of Stambaugh, Feo, and Manthei (1968), who showed that metronidazole was extensively metabolized, and of Taylor, Migliardi, and Schach von Wittenau (1970), who demonstrated the presence of nitroimidazole metabolites in serum from subjects who had taken metronidazole.

The decline of drug serum concentrations was much faster for metronidazole than for tinidazole. Half-lives of elimination, calculated from the chemical assay data, gave mean values of $7.3 \mathrm{hrs}$ for metronidazole and $12.5 \mathrm{hrs}$ for tinidazole (Table II). This difference in elimination rate for the two drugs results in a significant difference in their serum concentrations from $6 \mathrm{hrs}$ onwards. Thus, at $24 \mathrm{hrs}$, the serum concentration of tinidazole is three times that of metronidazole and at $48 \mathrm{hrs}$ it is five times that of metronidazole. No metronidazole was detectable in the serum at $72 \mathrm{hrs}$, whereas tinidazole was detected (mean $1.3 \mu \mathrm{g} . / \mathrm{ml}$.) in eight of the eleven subjects.

The present data are not amenable to a full pharmacokinetic analysis comparable to that carried out in the earlier study by Welling and Monro (1972), in which much smaller single doses of the drugs were used (tinidazole $150 \mathrm{mg}$; metronidazole $200 \mathrm{mg}$.). In the present study zero-order absorption was probably occurring during the initial tablet disintegration-dissolution process, which may be rate-limiting at high doses. However, the serum concentrations and areas under the concentration/ time curves for the two studies are approximately in proportion to the dose administered. In addition there is no significant difference between the elimination half-lives for the two studies (Table II). This comparison suggests that the pharmacokinetics of the two drugs are not dose-dependent over the range of $150-2,000 \mathrm{mg}$.

TABLE II Mean half-lives for elimination of tinidazole and metronidazole after single doses of 2 or $0 \cdot 2 \mathrm{~g}$.

\begin{tabular}{|c|c|c|}
\hline Dose (g.) & 2 & $0 \cdot 2$ \\
\hline $\begin{array}{l}\text { Tinidazole half-life (hrs) } \\
\text { Metronidazole half-life (hrs) }\end{array}$ & $\begin{array}{r}12.5 \pm 0.5 \\
7 \cdot 3 \pm 0.5\end{array}$ & $\begin{aligned} 12 \cdot 2 & \pm 0.8^{\star} \\
6.2 & \pm 0.8\end{aligned}$ \\
\hline
\end{tabular}

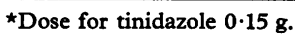

Individual data for the $2 \mathrm{~g}$. dose fitted to the equation $y=a x+b$ where $y=$ time and $x=\log$ (serum concentration). Only data giving a coefficient of correlation of 0.99 or greater were used (eight subiects for both drugs). Data for the $\mathbf{0 . 2} \mathrm{g}$. dose taken from Table IV of Welling and Monro (1972)

Our results are in reasonable agreement with those reported by Csonka (1971) and Woodcock (1972) for serum concentrations after a $2 \mathrm{~g}$. dose of metronidazole. We have now shown that, although metronidazole achieves higher peak serum concentrations of biologically active compounds after a singe $2 \mathrm{~g}$. dose than does tinidazole, the longer half-life of tinidazole results in higher serum concentrations from $4 \mathrm{hrs}$ onwards, which may result in a greater therapeutic effectiveness.

\section{Summary}

Serum concentrations of tinidazole and metronidazole have been measured in healthy female volunteers who received a single dose of $2 \mathrm{~g}$. of each drug in a cross-over study. Bioassays against $T$. vaginalis showed that metronidazole achieved higher peak concentrations (mean $81 \mu \mathrm{g} . / \mathrm{ml}$.) than did tinidazole (mean $67 \mu \mathrm{g} . / \mathrm{ml}$.), while assays for unchanged drug showed higher peak concentrations of tinidazole (mean $51 \mu \mathrm{g} . / \mathrm{ml}$.) than of metronidazole (mean $40 \mu \mathrm{g} . / \mathrm{ml}$.). This discrepancy is probably due to the presence in the serum of active metabolites of metronidazole. The longer half-life of tinidazole led to significantly higher serum concentrations (by bioassay and chemical assay) of tinidazole than of metronidazole from $6 \mathrm{hrs}$ onwards.

We wish to thank Dr. M. K. Flood who selected the subjects and took all the blood samples, Miss Beverley Johns who carried out the chemical assays, and Mr. D. Buggey who carried out the bioassays. 


\section{Addendum}

Since this paper was prepared, Forsgren and Wallin (1974) have published serum bioassay data for man after a single $2 \mathrm{~g}$. dose of tinidazole. This showed that trichomonicidal concentrations for most strains of $T$. vaginalis were maintained for $48 \mathrm{hrs}$. The bioassay results were rather lower than those reported here, probably because of the different end-point used in the two studies (MIC in our study, MCC (minimum trichomonicidal concentrations) by Forsgren and Wallin).

In addition to the references given to the use of a single $2 \mathrm{~g}$. dose of tinidazole in the treatment of $T$. vaginalis infections, Wallin and Forsgren (1974) found a cure rate of 96 per cent., while Swarz and Lahon (1974), summarizing a multinational study involving 379 patients, report a cure rate of 94 per cent.

\section{References}

CsonkA, G. W. (1971) Brit. f. vener. Dis., 47, 456 ForsGren, A., and WALLIN, J. (1974) Ibid., 50, 146

Howes, H. L., LyNCH, J. E., and Kivlin, J. L. (1970) "Antimicrobial Agents and Chemotherapy-1969", ed. G. L. Hobby, p. 261

RösemanN, G. W. E., and Vaughan, J. (1973) S. Afr. med. F., 47, 1222

Stambaugh, J. E., Feo, L. G., and Manthei, R. W. (1968) f. Pharm. exp. Ther., 161, 373

Swarz, H., and LaHON, H. F. J. (eds) (1974) Curr. med. Res. Opin., 2, no. 3 (Individual contributions by Bedoya, J. M.; Dellenbach, P., and Muller, P.; Mílek, E., and Nedelková, E.; Quartararo, P., and Fiorino, S.; Schellen, Ton M. C. M., and MeiN- hardt, G.; SchmõR, J.; Swarz, H.; Thavabalan, P. B., and Oriel, J. D.; Weidenbach, A., and Leix, H.)

TAYLOR, J. A., Migliardi, J. R., and Schach voN WittenaU, M. (1970) 'Antimicrobial Agents and Chemotherapy-1969', ed. G. L. Hobby, p. 267

WALLIN, J., and ForsGren, A. (1974) Brit. F. vener. Dis., 50, 148

Welling, P. G., and Monro, A. M. (1972) Arzneimittel Forsch., 22, 2128

Woodcock, K. R. (1972) Brit. F. vener. Dis., 48, 65

La pharmacocinétique du tinidazole et du métronidazole chez les femmes après une administration de fortes doses orales

\section{SOMMAIRE}

Les concentrations sériques du tinidazole et du métronidazole ont été mesurées chez des femmes volontaires saines qui recevaient une dose unique de $2 \mathrm{~g}$. de chaque médicament au cours d'une étude croisée. Les essais biologiques sur $T$. vaginalis montrèrent que le métronidazole atteint des concentrations maximales plus hautes (moyenne $81 \mu \mathrm{g} / \mathrm{ml}$ ) que le tinidazole (moyenne $67 \mu \mathrm{g} / \mathrm{ml}$ ), alors que les dosages du médicament non métabolisé montraient des concentrations maximales plus hautes pour le tinidazole (moyenne $51 \mu \mathrm{g} / \mathrm{ml}$ ) que pour le métronidazole (moyenne $40 \mu \mathrm{g} / \mathrm{ml}$ ). Ce désaccord est dû probablement à la présence dans les sérums de métabolites actifs du métronidazole. La demi-vie plus longue du tinidazole donne des concentrations sériques significativement plus hautes (par les essais biologiques et chimiques) pour le tinidazole que pour le métronidazole à partir de la sixième heure. 